\title{
Differential patterns of distribution of limpets on intertidal seawalls: experimental investigation of the roles of recruitment, survival and competition
}

\author{
L. Iveša ${ }^{1, *}$, M. G. Chapman ${ }^{2}$, A. J. Underwood ${ }^{2}$, R. J. Murphy ${ }^{2}$ \\ ${ }^{1}$ Ruder Bošković Institute, Center for Marine Research, G. Paliaga 5, 52210 Rovinj, Croatia \\ ${ }^{2}$ Centre for Research on Ecological Impacts of Coastal Cities, School of Biological Sciences A11, University of Sydney, \\ New South Wales 2006, Australia
}

\begin{abstract}
On artificial surfaces (seawalls) in Sydney Harbour (Australia), local biodiversity of grazers differs between sandstone and concrete constructions because limpets Siphonaria denticulata are more abundant on sandstone, while Patelloida latistrigata are more abundant on concrete walls. Competition between siphonarian and patellid limpets is unstudied on artificial structures, although the limpets are common and are known to compete in natural habitats. We tested hypotheses that the substratum (concrete or sandstone), intra- and/or interspecific competition, or a combination of factors, influence recruitment, survival, rates of grazing, or the quantity and types of algal food to explain the observed patterns. Such analyses enable better understanding of the processes influencing diversity. Both species recruited more to concrete than to sandstone plates. S. denticulata recruited more in the presence of conspecifics and slightly less in the presence of $P$. latistrigata. Results varied between locations and experiments, but each species survived better on concrete, which had more macro- and micro-algal food. Increased densities of P. latistrigata reduced survival of conspecifics and of $S$. denticulata. S. denticulata had no effect on survival of $P$. latistrigata, but reduced amounts of macro-algae. P. latistrigata did not affect macro-algae. Initially, there were more micro-algae on concrete and a minor effect of large densities of $S$. denticulata. After $95 \mathrm{~d}$, differences between habitats decreased and P. latistrigata were more strongly associated with reduced amounts of micro-algae. Neither substratum, density, nor mix of limpets affected rates of grazing. Thus, interspecific interactions were similar to predictions from knowledge of natural habitats, despite the different characteristics of artificial habitats and the reduced intertidal area available for grazing. Recruitment and competition were important in explaining different densities of these limpets on sandstone and concrete walls. Increasing urbanization requires more experimental tests to identify how well current theories of intertidal ecology and of the processes maintaining local biodiversity can apply to artificial shorelines.
\end{abstract}

KEY WORDS: Artificial structures $\cdot$ Habitat $\cdot$ Competition $\cdot$ Grazing $\cdot$ Intertidal $\cdot$ Limpets

\section{INTRODUCTION}

Increasing urbanization raises many concerns about sustainability of biodiversity in terrestrial (Laurie 1979, Breuste et al. 1998, McIntyre 2000) and marine (Suchanek 1994, Smith et al. 2000) habitats. Despite many definitions of biodiversity (May 1994), it is often esti- mated as numbers and types of species in an area, usually by sampling, or from compiled lists of species. Counts of species do not, however, provide information about variability in distributions and abundances of species due to environmental changes or biological processes. Yet, ecological interactions among species, e.g. between resources and consumers or competitors 
and between organisms and the environment, determine sustainability of diversity in the long term, because these processes largely determine patterns of abundance of individual species. The focus of the present study is to investigate the ecological processes that maintain biodiversity in artificial settings.

There has been growing awareness of changes to shorelines due to urbanization, especially along estuarine shores (e.g. Attrill et al. 1999, Glasby \& Connell 1999, Moschella et al. 2005, Marzinelli et al. 2009). For example, more than $70 \%$ of the shoreline of San Diego Bay, California (Davis et al. 2002) and approximately $50 \%$ of the shoreline of Sydney Harbour, Australia (Chapman 2003) is artificial, mainly composed of seawalls. Seawalls and similar infrastructure are built to prevent erosion and for commercial, residential, or recreational purposes. They replace natural intertidal or subtidal rocky and sedimentary shores, potentially disrupting connectivity among populations (Bulleri \& Airoldi 2005), providing stepping stones or corridors for spread of invasive species (Bulleri et al. 2006), and affecting assemblages in adjacent habitats (Goodsell et al. 2007). Environmental impacts of 'armouring' of shores are likely to worsen with climatic change, due to rising sea levels and increased frequency of storms, requiring more artificial protection of coastlines.

Seawalls in Sydney Harbour provide intertidal habitat, but do not support natural assemblages (Chapman \& Bulleri 2003, Bulleri et al. 2005). Common species on rocky shores may be found at unnatural densities or are absent from seawalls (Chapman 2003, 2006, Moreira et al. 2006, Jackson et al. 2008). The most abundant grazing animals on seawalls are limpets, which are major components of assemblages on natural intertidal shores, structuring algal and faunal assemblages (Branch 1981, Hawkins \& Hartnoll 1983, Underwood et al. 1983). There is currently no information about how interactions among these grazers might differ on vertical seawalls that compress distributions of intertidal species, nor how changes to these interactions might determine differences between assemblages on walls compared to natural shores.

Intertidal areas on most natural shores in New South Wales (NSW) are extensive wave-cut platforms with abundant space for the large diversity of grazers. On natural shores, small limpets Patelloida latistrigata and Siphonaria denticulata are usually found in different areas, with the latter more abundant lower on the shore (Creese \& Underwood 1982). P. latistrigata are outcompeted by the larger Cellana tramoserica and the former are mainly found in refuges among barnacles (Creese 1982), where they feed on micro-algae and, to a lesser extent, germlings of macro-algae (Jernakoff 1985). C. tramoserica also outcompete $S$. dentic- ulata, but intraspecific competition generally reduces densities of $C$. tramoserica before they can eliminate S. denticulata locally (Creese \& Underwood 1982). If macro-algae develop, $S$. denticulata can persist, feeding on these larger plants which are not food for $C$. tramoserica.

On intertidal seawalls in Sydney Harbour, Patelloida latistrigata and Siphonaria denticulata are generally more abundant than on natural shores, although there is great variation from place to place (Bulleri et al. 2005). These species are also found in close proximity because of the small intertidal range on vertical walls. Moreira (2006) documented differences in abundances between different types of walls. P. latistrigata were more abundant on concrete than on sandstone seawalls; $S$. denticulata showed the opposite pattern. Differences in relative abundances on different types of walls and the restricted area over which animals may forage could therefore change or intensify interactions between these species from those found on natural shores.

Differences in local biodiversity are a direct consequence of any differences in relative abundances of species (including being absent versus present) in different areas or on different substrata. Understanding how diversity is controlled or maintained is more likely if the processes regulating different relative abundances are themselves understood. In this study, a number of models that might explain differences in abundances of Patelloida latistrigata and Siphonaria denticulata between concrete and sandstone seawalls were examined using a manipulative field experiment. The models tested were that differences in abundance between the 2 species on concrete and sandstone walls were due to differential recruitment and/or survival of adults, each of which may be mediated by the substratum itself, by the presence of the other species and/or by a combination of both factors. Specific hypotheses examined were: (1) P. latistrigata will recruit more to concrete and $S$. denticulata will show the opposite pattern, irrespective of the species present; (2) each species will recruit more to plates where the other species is absent, irrespective of substratum; (3) recruitment will be influenced by the substratum and by the species present; (4) adult $P$. latistrigata will survive better on concrete and $S$. denticulata better on sandstone, irrespective of the presence of the other species; (5) each species will survive better on plates where the other species is absent, irrespective of the substratum; (6) survival of adults of each species will differ according to the combination of substratum and species present.

Densities of limpets on intertidal shores in NSW are strongly influenced by availability of food (Underwood et al. 1983). Patelloida latistrigata and 
Siphonaria denticulata usually consume different types of algae, the former mostly eating micro-algae and the latter eating macro-algae (Creese 1982, Creese \& Underwood 1982). Interspecific interference competition might alter the rates at which different species forage. Thus, survival of these limpets on different surfaces in the presence of the other species might be related to availability of food, or the rates at which food is consumed. These models were examined by testing the following hypotheses: (7) there will be different quantity/types of algae on concrete and sandstone plates, irrespective of the species present; (8) algae will differ according to the species present, but not the substratum; (9) a combination of substratum and species will determine the quantity/types of algae; (10) rates of grazing will differ between concrete and sandstone, irrespective of the species present; (11) grazing rates will differ according to the species present, but not the substratum; (12) grazing will be influenced by the substratum and species present.

\section{MATERIALS AND METHODS}

Sandstone and concrete seawalls are generally located in different parts of the harbour and are thus subjected to different environmental conditions, have different extant assemblages, are of different ages and so forth. There are also many restrictions about attaching experimental structures, such as cages, onto some seawalls in the harbour, so experiments were done using concrete and sandstone plates attached to 2 intertidal sandstone walls where Siphonaria denticulata were abundant. Each wall also had an adjacent (within $10 \mathrm{~m}$ ) concrete wall where Patelloida latistrigata were present in reasonably large densities, but attaching any structures to the concrete walls was not permitted.

A total of 20 concrete and 20 sandstone plates $(20 \times$ $20 \mathrm{~cm}$ ) were attached to each of 2 intertidal seawalls, at Careening Cove (CC) and Cremorne Point (CP) in Sydney Harbour (Fig. 1A). Four sandstone or concrete plates, arranged in random order, were attached to each of 10 frames, which were then screwed onto the walls at mid-tidal height, which is the range naturally occupied by these limpets on these seawalls (Fig. 1B). Each plate was surrounded by a fence ( $5 \mathrm{~mm}$ mesh) to prevent limpets from moving off or onto the plates.

The sampling protocol is given in Fig. 2. The plates were deployed $28 \mathrm{~d}$ prior to limpets being added to ensure that an algal film had developed (e.g. MacLulich 1986). Adult limpets were added to the plates on Day 0 (Start 1). Sizes of limpets were: Siphonaria denticulata, 9.3 to $16.6 \mathrm{~mm}$; Patelloida latistrigata, 8.9 to $15.5 \mathrm{~mm}$. The deployed limpets were thus larger than recruits ( $<4 \mathrm{~mm})$ and estimates of mortality were not confused by recruitment. Mortality of these adults in some treatments was relatively rapid, so the original numbers of limpets were re-established 16 (Start 2) and 81 d (Start 3) from Day 0 by adding new limpets to those surviving. At each time, limpets were deployed in 5 treatments: (A) 12Sd: $S$. denticulata at mean natural density found on sandstone walls (12 per plate, i.e. 12 per $400 \mathrm{~cm}^{2}$ ); (B) 9Pl: $P$. latistrigata at mean natural density on concrete walls (9 per plate). These densities were slightly larger than those given by Moreira (2006) to allow some initial mortality in response to any disturbance associated with the transplan-
Fig. 1. (A) Study sites in Sydney Harbour (Australia) and (B) method of attachment of plates onto the walls 


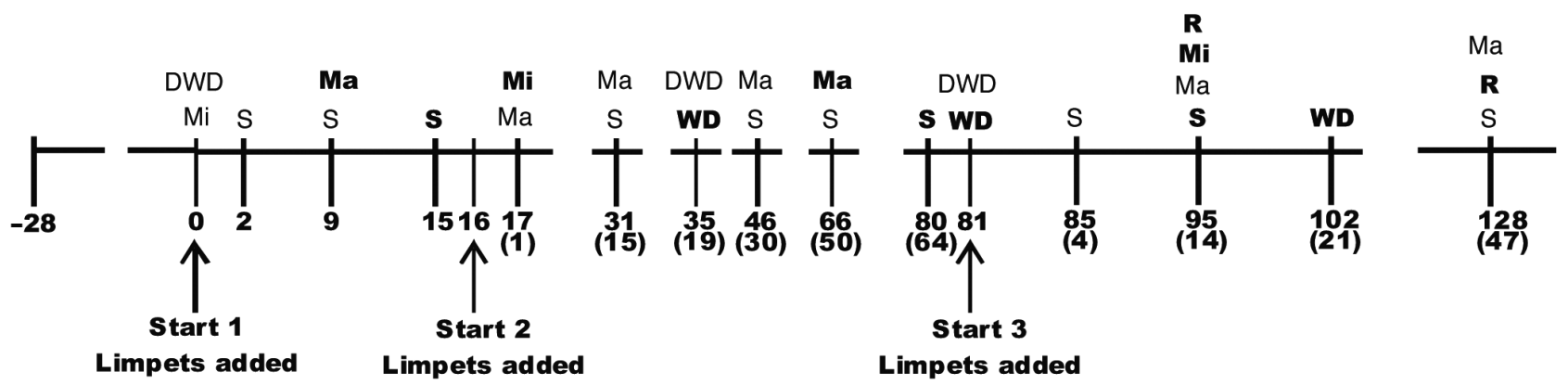

Fig. 2. Chronological sequence (days after starting the experiments on Day 0) showing times of measurement of survival (S), recruitment (R), quantity and types of micro-algae (Mi) and macro-algae (Ma) and amount of grazing (DWD: deployment of wax discs; WD: collection of wax discs). Data collected at times marked in bold were analysed. Numbers in parentheses show the days after the original numbers of limpets were re-established during Starts $2 \& 3$ of the experiments. Breaks in the time-line are periods of no activity

tation. To distinguish between effects of intra- and interspecific competition (Underwood 1986, 1992), there were 3 further treatments: (C) $12 \mathrm{Sd}+9 \mathrm{Pl}$ (or 9Pl + 12Sd, depending upon the focal species): $12 \mathrm{~S}$. denticulata plus 9 P. latistrigata; (D) 21Sd and (E) 21Pl: 21 $S$. denticulata or $21 P$. latistrigata, respectively. The limpets were deployed randomly amongst the experimental treatments and marked with non-toxic nail polish. Survival was measured at irregular intervals after each start (Fig. 2). Recruitment was measured twice towards the end of the experiment, after $95 \mathrm{~d}$ and again after $128 \mathrm{~d}$. Recruits were not removed between these 2 sampling periods.

During the experiment, a cover of green filamentous and foliose algae developed towards the lower edges (i.e. lower on the wall) of some plates, particularly the concrete plates. This cover was sampled from digital photos of each plate in situ at irregular intervals throughout the experiment (Fig. 2), using a grid of 100 regular points placed over each photo.

Micro-algae were sampled prior to and at irregular intervals after deployment of the limpets (Fig. 2). The plates were removed from the wall for a period of about $1 \mathrm{~h}$. There was no apparent disturbance to the limpets, which were immobile and firmly attached during low tide. The amounts of chlorophyll a ( $\mathrm{chl}$ a) were measured using colour-infrared imagery (Murphy et al. 2004) with a 3-CCD colour-infrared (CIR) camera (Geospatial Systems), which measures light at green (525 to $575 \mathrm{~nm}$ ), red (645 to $689 \mathrm{~nm}$ ) and near-infrared (NIR; 758 to $833 \mathrm{~nm}$ ) wavelengths. The images were converted to reflectance values using a calibration panel (30\% Spectralon; Labsphere). A ratio of red and near-infrared reflectances (NIR/red) is indicative of the amount of chl a on the substratum (Murphy et al. 2006). Because concrete and sandstone had different spectral properties, the relationships between $\mathrm{chl} a$ and NIR/red ratio were derived for each substratum using linear regressions to convert ratio values into amounts of chlorophyll:
Concrete:

Chl a $\left(\mu \mathrm{g} \mathrm{cm}^{-2}\right)=2.6221 \times(\mathrm{NIR} / \mathrm{red})-2.8956$

Sandstone:

Chl a $\left(\mu \mathrm{g} \mathrm{cm}^{-2}\right)=2.2823 \times(\mathrm{NIR} / \mathrm{red})-2.519$

The types of micro-algae present were determined using spectrometry (Murphy et al. 2005a). Reflectance spectra (350 to $1050 \mathrm{~nm}$ ) were recorded from the surface of each plate using a field spectrometer (FieldSpec Pro Analytical Spectral Devices), with spectra taken from 3 random locations on each plate from a height of $12 \mathrm{~cm}$ using a $25^{\circ}$ field-of-view fibreoptic. Each spectrum thus recorded an area of approximately $22 \mathrm{~cm}^{2}$. Prior to each spectrum being recorded, a calibration spectrum was recorded from a white reference panel ( 99\% Spectralon). Derivative analysis was used to enhance subtle absorption features and to separate overlapping absorptions (Murphy et al. 2005a). Reflectance data were converted to pseudo-absorbance units and fourth-derivative spectra (Bidigare et al. 1989) calculated using a combined smoothing and differentiation technique, with a $24 \mathrm{~nm}$ smoothing window (Savitzky \& Golay 1964, Steinier et al. 1972). Absorptions by different pigments were identified as separate peaks and the absorption by each pigment extracted from each spectrum as the maximal derivative value for each peak above the zero-baseline. Derivative reflectance increased with increasing amounts of pigment. Absorptions associated with different pigments were identified in the spectra from published wavelengths of absorption by pigments in vivo (Murphy et al. 2005b), specifically: carotenoids ( 546 nm), phyco-erythrocyanin $(\sim 575 \mathrm{~nm})$, chlorophyll $c(\mathrm{chl} c)$ $(\sim 640 \mathrm{~nm})$, chlorophyll $b(\mathrm{chl} b)(\sim 650 \mathrm{~nm})$ and chl $a$ ( 680 nm).

To test hypotheses about rates of grazing, 4 wax discs (12 mm diam.) were inserted into each plate (see Thompson et al. 1997 for details) and the radular marks of Patelloida latistrigata and Siphonaria denticulata 
scored after deployment for different periods of time, after 35 d, again after $46 \mathrm{~d}$ and again after $21 \mathrm{~d}$ (Fig. 2). Although individual radular marks were identified, they frequently obscured those below, making counts difficult. Therefore, each wax disc was divided into 8 sectors and the numbers of sectors containing radular marks of each species recorded.

\section{RESULTS}

\section{Recruitment}

Because very small Siphonaria denticulata are difficult to distinguish from other species of Siphonaria in the field, all small $(<2 \mathrm{~mm})$ Siphonaria were counted in situ and a random sample of $>50$ individuals was collected for later identification in the laboratory. More than $90 \%$ of these were juvenile $S$. denticulata; the others were mostly $S$. virgulata. Recruits of Siphonaria were therefore considered to be $S$. denticulata.

More Siphonaria denticulata recruited than did Patelloida latistrigata, with most recruitment of $S$. denticulata at CC. After 128 d, over all 40 plates, there was a total of 701 recruits, but only 69 at CP. At CC (Fig. 3), there were more recruits on concrete (420) than on sandstone $\left(281 ; \chi^{2}=27.6, \mathrm{p}<10^{-6}\right)$, which does not support Hypothesis 1 . There was also substantially more recruitment onto plates with adult $S$. denticulata (a total of 622 on treatments $12 \mathrm{Sd}, 21 \mathrm{Sd}$ and $12 \mathrm{Sd}+9 \mathrm{Pl}$ ) than to treatments without (a total of 79 on treatments 9Pl, 21Pl), providing support for Hypothesis 3. To make comparisons using the same number of plates, recruitment of $S$. denticulata to $12 \mathrm{Sd}$ and $21 \mathrm{Sd}$ was compared to recruitment to $9 \mathrm{Pl}$ and $21 \mathrm{Pl} ; \chi^{2}=235.6, \mathrm{p}<10^{-54}$. There was also significantly less difference between

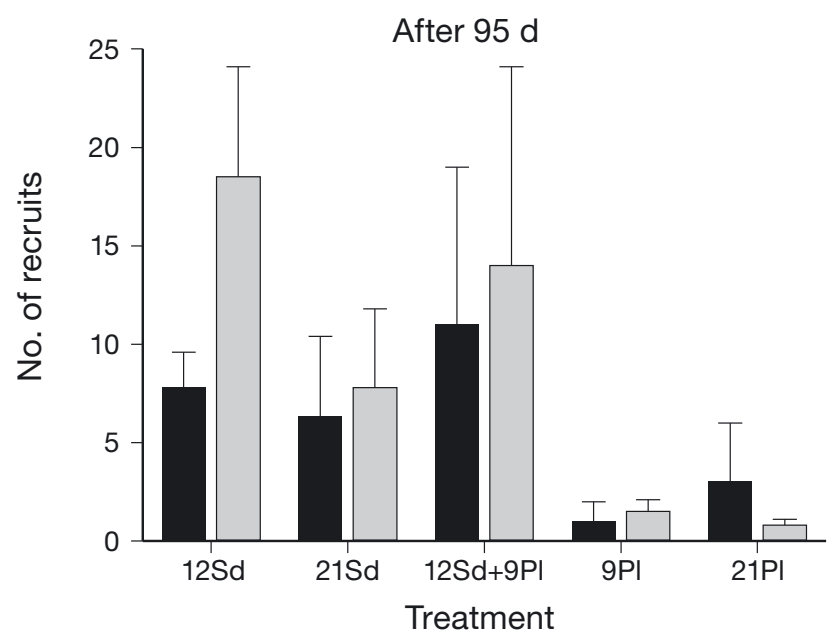

recruitment on concrete than on sandstone on plates with $S$. denticulata than was the case on plates without these limpets (Fig. $3 ; \chi^{2}=81.1, \mathrm{p}<10^{-18}$ ). In support of Hypothesis 2, the presence of P. latistrigata did, however, reduce recruitment by $S$. denticulata; there were 306 recruits on treatment $12 \mathrm{Sd}$ and only 179 on $12 \mathrm{Sd}+$ 9P1. At CP, Hypotheses $1 \& 2$ were again not supported - there were more recruits on concrete (42) than on sandstone (27) and more with (52) than without (17) $S$. denticulata, but no influence of $P$. latistrigata $(20$ recruits on treatment $12 \mathrm{Sd}$ and 22 on treatment $12 \mathrm{Sd}+$ 9Pl). Probably because there were fewer recruits at this location, these differences were not significant in $\chi^{2}$ tests. Only 9 recruits of $P$. latistrigata were found, but, in support of Hypothesis 1, 8 of these were on concrete plates (binomial test; $\mathrm{p}<0.05$ ).

\section{Survival}

The proportional survival of the deployed limpets of each species was analysed separately using a 3 factor analysis of variance (ANOVA) for each of 3 times: $15 \mathrm{~d}$ after Start 1 (Time 1), $64 \mathrm{~d}$ after Start 2 (Time 2) and $14 \mathrm{~d}$ after Start 3 (Time 3), just prior to resetting the original densities each time. Although the experiment was continued for 128 d, very few Patelloida latistrigata were found alive at $\mathrm{CP}$ at this time in any treatment, which compromised examination of any interactions between P. latistrigata and Siphonaria denticulata. Therefore, this time of sampling was not analysed.

Significantly more Patelloida latistrigata survived on concrete than on sandstone plates at Times 1 \& 2 (Table 1). At Time 3, there was no significant difference, but a similar trend was observed. These results are consistent with Hypothesis 4. There was no signifi-

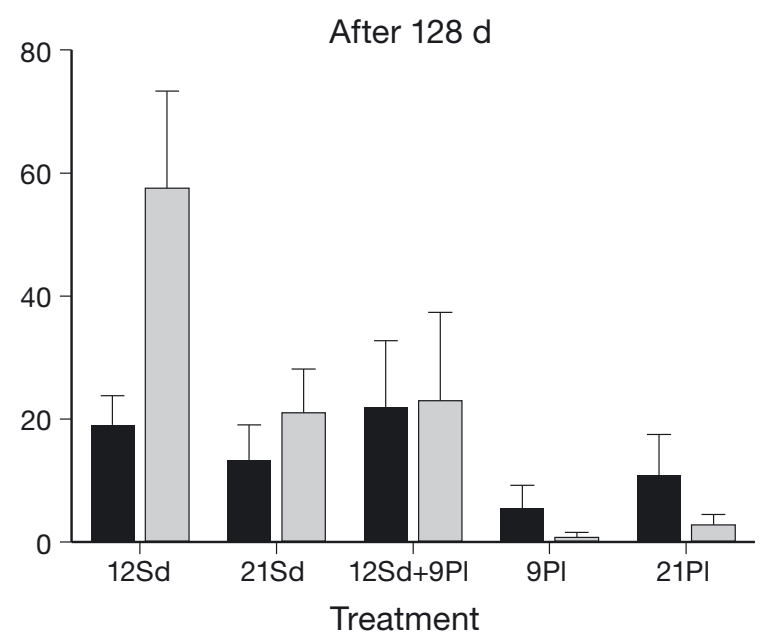

Fig. 3. Mean $( \pm S E ; n=4)$ recruitment of Siphonaria denticulata for each experimental treatment (see 'Materials and methods' for treatments) at Careening Cove after 95 and 128 d; black bars: sandstone plates; grey bars: concrete plates 
Table 1. Analyses of proportions of surviving Patelloida latistrigata on sandstone and concrete plates (substratum, fixed factor) at Careening Cove and Cremorne Point (locations, random factor) in 3 treatments $(9 \mathrm{Pl}, 21 \mathrm{Pl}$ and $9 \mathrm{Pl}+12 \mathrm{Sd}$, fixed factor; Treatments B, E and C, respectively, as described in 'Materials and Methods'); Time 1: $15 \mathrm{~d}$ after Start 1, Time 2: 64 days after Start 2, Time 3: 14 days after Start 3 (details in 'Materials and Methods'). L: location; S: substratum; T: treatment. ${ }^{\mathrm{ns}} \mathrm{p}>0.05,{ }^{*} \mathrm{p}<0.05,{ }^{* *} \mathrm{p}<0.01$

\begin{tabular}{|c|c|c|c|c|c|c|c|}
\hline \multirow[t]{2}{*}{ Source } & \multirow[t]{2}{*}{ df } & \multicolumn{2}{|c|}{ Time 1} & \multicolumn{2}{|c|}{ Time 2} & \multicolumn{2}{|c|}{ Time 3} \\
\hline & & MS & $F$ & MS & $F$ & MS & $F$ \\
\hline $\mathrm{L}$ & 1 & 0.04 & $0.81^{\mathrm{b}}$ & 0.14 & $6.06 * \mathrm{~b}$ & 3.86 & $164.43^{* * a}$ \\
\hline $\mathrm{S}$ & 1 & 0.38 & $7.28^{* b}$ & 0.12 & $5.07 * b$ & 0.03 & 0.64 \\
\hline $\mathrm{T}$ & 2 & 0.24 & 2.00 & 0.02 & 0.43 & 0.06 & 1.10 \\
\hline $\mathrm{L} \times \mathrm{S}$ & 1 & 0.00 & $0.01^{\mathrm{a}}$ & 0.02 & $0.65^{\mathrm{a}}$ & 0.04 & $1.81^{\mathrm{a}}$ \\
\hline $\mathrm{L} \times \mathrm{T}$ & 2 & 0.12 & $2.24^{\mathrm{b}}$ & 0.05 & $1.91^{\mathrm{b}}$ & 0.05 & $2.23^{\mathrm{a}}$ \\
\hline $\mathrm{S} \times \mathrm{T}$ & 2 & 0.02 & $0.33^{\mathrm{b}}$ & 0.00 & $0.02^{\mathrm{b}}$ & 0.02 & $0.65^{\mathrm{a}}$ \\
\hline $\mathrm{L} \times \mathrm{S} \times \mathrm{T}$ & 2 & 0.02 & 0.36 & 0.00 & 0.18 & 0.01 & 0.41 \\
\hline Residual & 36 & 0.06 & & 0.03 & & 0.02 & \\
\hline Cochran's & st $(C)$ & $0.24^{\mathrm{n}}$ & & $0.16^{\mathrm{ns}}$ & & $0.21^{\mathrm{n}}$ & \\
\hline \multicolumn{8}{|c|}{ Student-Newman-Keuls (SNK) tests, mean (SE): } \\
\hline \multicolumn{8}{|c|}{$\begin{array}{l}\text { Student-Newman-Keuls (SNK) tests, mean (SE): } \\
\text { Time } 1 \quad \text { (Concrete) } 0.58(0.05)>\text { (Sandstone) } 0.36(0.05)\end{array}$} \\
\hline \multicolumn{8}{|c|}{ Time $2 \quad$ (Concrete) $0.37(0.03)>$ (Sandstone) $0.27(0.03)$} \\
\hline \multicolumn{8}{|c|}{ Tested against: } \\
\hline \multicolumn{8}{|c|}{ apooled Residual and $\mathrm{L} \times \mathrm{S} \times \mathrm{T}$} \\
\hline \multicolumn{8}{|c|}{${ }^{b}$ Pooled Residual, $\mathrm{L} \times \mathrm{S} \times \mathrm{T}$ and $\mathrm{L} \times \mathrm{S}$} \\
\hline
\end{tabular}

though again this was not always significant (Table 2). Adding P. latistrigata always caused greater mortality of $S$. denticulata than was caused by adding more $S$. denticulata. These results are in agreement with Hypothesis 5.

\section{Amounts and types of algae}

Prior to deploying the limpets, many concrete plates had developed a layer of Enteromorpha spp., Ulvales and Cladophorales (with fronds up to $1.5 \mathrm{~cm}$ long) along the lower third of the plate, which persisted throughout the experiment. This result is in agreement with Hypothesis 8, but only for macro-algae. There was little cover on the upper parts of the plates, so percentage covers of macro-algae were estimated from the digital photos separately for the upper cant effect of treatment on survival of $P$. latistrigata, with large variability among plates.

Because of the large amount of variability among plates, the data were tested further by pooling survivors of Patelloida latistrigata across replicate plates. There were no significant interactions among locations, substrata and treatments (3 factor $\chi^{2}$ test, $\mathrm{p}>$ 0.05 ), nor between substrata and treatments ( 2 factor $\chi^{2}$ test, $\mathrm{p}>0.05$ ) when data from the 2 locations were pooled. There was a trend for fewer survivors on each substratum where densities were larger, i.e. 21 versus 9 P. latistrigata, although this was not always significant, and there was only a small difference on sandstone at Time 3. There was no consistent effect on survival of P. latistrigata due to adding Siphonaria denticulata (compare 9Pl with 9Pl $+12 \mathrm{Sd}$ in Table 2), rejecting Hypothesis 5.

Significantly more Siphonaria denticulata survived on concrete than on sandstone plates at each time (Table 3), which is the opposite prediction to that in Hypothesis 4 for this species. Survival of $S$. denticulata differed significantly among treatments at Times $2 \& 3$, but StudentNewman-Keuls (SNK) tests failed to identify differences among means. The data were therefore further tested using $\chi^{2}$ tests (Table 2). Again, there were no significant interactions between locations, substrata and treatments, nor substrata and treatments ( $\chi^{2}$ tests, $\left.\mathrm{p}>0.05\right)$. Except for Time 1 on concrete, adding $S$. denticulata (21Sd versus 12Sd) or Patelloida latistrigata (12Sd + 9Pl versus $12 \mathrm{Sd}$ decreased survival of $S$. denticulata, al-
Table 2. $\chi^{2}$ tests of numbers of surviving limpets in each treatment at Times 1, 2 \& 3 (see Table 1 for explanations); data are numbers (proportions) surviving, summed over 5 replicate plates and 2 locations. ${ }^{*} \mathrm{p}<0.05,{ }^{* *} \mathrm{p}<0.01$

\begin{tabular}{|c|c|c|c|c|}
\hline & 9Pl & $\begin{array}{c}\text { Treatments } \\
21 \mathrm{Pl}\end{array}$ & $9 \mathrm{Pl}+12 \mathrm{Sd}$ & $\chi^{2}$ \\
\hline \multicolumn{5}{|c|}{ Patelloida latistrigata } \\
\hline \multicolumn{5}{|c|}{ Concrete } \\
\hline Time 1 & $57(0.63)$ & $86(0.41)$ & $61(0.68)$ & $20.45^{* *}$ \\
\hline Time 2 & $38(0.42)$ & $71(0.34)$ & $32(0.36)$ & 1.31 \\
\hline Time 3 & $59(0.65)$ & $107(0.51)$ & $61(0.68)$ & $7.76^{*}$ \\
\hline \multicolumn{5}{|c|}{ Sandstone } \\
\hline Time 1 & $42(0.47)$ & $61(0.29)$ & $39(0.43)$ & $9.48^{*}$ \\
\hline Time 2 & $28(0.31)$ & $53(0.25)$ & $23(0.26)$ & 0.67 \\
\hline Time 3 & $51(0.57)$ & $113(0.54)$ & $54(0.60)$ & 0.83 \\
\hline \multirow{3}{*}{$\begin{array}{c}\text { Total no. } \\
\text { at start }\end{array}$} & 90 & 210 & 90 & \multirow{3}{*}{$\chi^{2}$} \\
\hline & & Treatments & & \\
\hline & $12 \mathrm{Sd}$ & 21Sd & $12 \mathrm{Sd}+9 \mathrm{Pl}$ & \\
\hline \multicolumn{5}{|c|}{ Siphonaria denticulata } \\
\hline \multicolumn{5}{|c|}{ Concrete } \\
\hline Time 1 & $110(0.92)$ & $200(0.95)$ & $97(0.81)$ & 5.63 \\
\hline Time 2 & $103(0.86)$ & $162(0.77)$ & $88(0.73)$ & 5.94 \\
\hline Time 3 & $112(0.93)$ & $179(0.85)$ & $101(0.84)$ & 3.64 \\
\hline \multicolumn{5}{|c|}{ Sandstone } \\
\hline Time 1 & $98(0.82)$ & $139(0.66)$ & $76(0.63)$ & $10.55^{* *}$ \\
\hline Time 2 & $88(0.73)$ & $128(0.61)$ & $61(0.51)$ & $10.75^{* *}$ \\
\hline Time 3 & $106(0.88)$ & $166(0.79)$ & $89(0.74)$ & 5.64 \\
\hline $\begin{array}{c}\text { Total no. } \\
\text { at start }\end{array}$ & 120 & 210 & 120 & \\
\hline
\end{tabular}


Table 3. Analyses of proportions of surviving Siphonaria denticulata on sandstone and concrete plates. See Table 1 for details of experimental design and abbreviations. ${ }^{\mathrm{ns}} \mathrm{p}>0.05,{ }^{*} \mathrm{p}<0.05,{ }^{* *} \mathrm{p}<0.01,{ }^{* * *} \mathrm{p}<0.001$

\begin{tabular}{|c|c|c|c|c|c|c|c|}
\hline \multirow[t]{2}{*}{ Source } & \multirow[t]{2}{*}{ df } & \multicolumn{2}{|c|}{ Time 1} & \multicolumn{2}{|c|}{ Time 2} & \multicolumn{2}{|c|}{ Time 3} \\
\hline & & MS & F & MS & $F$ & MS & $F$ \\
\hline $\mathrm{L}$ & 1 & 0.03 & $0.37^{\mathrm{c}}$ & 0.00 & $0.10^{\mathrm{c}}$ & 0.18 & $13.87^{* * * \mathrm{c}}$ \\
\hline $\mathrm{S}$ & 1 & 0.30 & $4.50 * \mathrm{c}$ & 0.29 & $8.25^{* * \mathrm{C}}$ & 0.06 & $4.70^{* \mathrm{c}}$ \\
\hline $\mathrm{T}$ & 2 & 0.11 & $1.61^{\mathrm{c}}$ & 0.16 & $4.46^{* \mathrm{c}}$ & 0.05 & $3.88^{* \mathrm{c}}$ \\
\hline $\mathrm{L} \times \mathrm{S}$ & 1 & 0.02 & $0.34^{\mathrm{a}}$ & 0.02 & $0.45^{\mathrm{a}}$ & 0.02 & $1.28^{\mathrm{a}}$ \\
\hline $\mathrm{L} \times \mathrm{T}$ & 2 & 0.02 & $0.27^{\mathrm{b}}$ & 0.02 & $0.66^{\mathrm{b}}$ & 0.00 & $0.08^{\mathrm{b}}$ \\
\hline $\mathrm{S} \times \mathrm{T}$ & 2 & 0.01 & $0.13^{\mathrm{c}}$ & 0.00 & $0.11^{\mathrm{c}}$ & 0.00 & $0.24^{\mathrm{c}}$ \\
\hline $\mathrm{L} \times \mathrm{S} \times \mathrm{T}$ & 2 & 0.01 & 0.16 & 0.00 & 0.11 & 0.01 & 0.11 \\
\hline Residual & 36 & 0.07 & & 0.04 & & 0.01 & \\
\hline Cochran's tes & $t(C)$ & $0.26^{\mathrm{n}}$ & & $0.21^{\mathrm{ns}}$ & & $0.31^{\mathrm{n}}$ & \\
\hline \\
\hline \multicolumn{8}{|c|}{$\begin{array}{l}\text { SNK tests, mean (SE): } \\
\begin{array}{ll}\text { Time } 1 & \text { (Concrete) } 0.86(0.04)>(\text { Sandstone) } 0.70(0.04)\end{array}\end{array}$} \\
\hline \multicolumn{8}{|c|}{$\begin{array}{ll}\text { Time } 2 & \text { (Concrete) } 0.78(0.03)>\text { (Sandstone) } 0.62(0.05) \\
\text { Treatments } & \text { No sionificant differences among means identified by SNK }\end{array}$} \\
\hline Treatments & $\mathrm{N}$ & gnifica & at differe & es amol & g means & lentifi & d by SNK \\
\hline \multicolumn{8}{|c|}{ (Concrete) $0.87(0.02)>$ (Sandstone) $0.80(0.03)$} \\
\hline \multicolumn{8}{|c|}{ Jo significant differences among means identified by SNK } \\
\hline \multicolumn{8}{|c|}{ Tested against: } \\
\hline \multicolumn{8}{|c|}{ 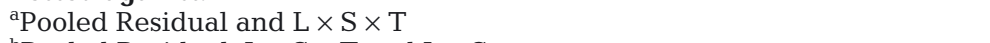 } \\
\hline \multicolumn{8}{|c|}{${ }^{\circ}$ Pooled Residual, $\mathrm{L} \times \mathrm{S} \times \mathrm{T}$ and $\mathrm{L} \times \mathrm{S}$} \\
\hline${ }^{\mathrm{c}}$ Pooled Resid & ual, L & $5 \times T_{1}$, & $\times \mathrm{S}$ and & & & & \\
\hline
\end{tabular}

and lower $40 \%$ of each plate. Data were analysed 9 and $66 \mathrm{~d}$ after limpets were deployed the first time. Because data from the upper and lower surfaces of the same plate are not independent, 2 randomly selected plates of each treatment were analysed for the upper surface and 2 different plates for the lower surface. Substratum, treatment and height were fixed factors, location was a random factor.

After $9 \mathrm{~d}$, there was no difference between the 2 locations, nor significant interactions between locations and any other factor (all p values $>0.25$ ). There was, how- ever, a significant interaction among substrata, treatments and heights on the plate $\left(F_{4,40}=7.04, \mathrm{p}<0.05\right)$. There was zero cover on all upper levels, very little cover on the lower level on the sandstone plates and no differences among treatments (Fig. 4). On concrete plates, there was significantly less cover on the lower $40 \%$ of those plates with 12 or 21 Siphonaria denticulata compared to those plates with only Patelloida latistrigata. Where $P$. latistrigata were present without $S$. denticulata $(9 \mathrm{Pl})$, there was significantly more cover on the lower than on the upper $40 \%$ of concrete plates (Fig. 4). Although data were not collected from the upper and lower $40 \%$ of the plates prior to deployment of the limpets, treatments were assigned to plates randomly and there is no reason to expect that, prior to the limpets being deployed, there would have been any difference in macro-algal cover between plates allocated to treatments with or without $S$. denticulata.

After $66 \mathrm{~d}$, a similar pattern was found - a significant interaction among substrata, treatments and heights on the plate $\left(F_{4,40}=15.81, \mathrm{p}<0.001\right)$ and no difference between locations. Patterns among substrata, treatments and heights were similar to those found after $9 \mathrm{~d}$ (Fig. 4).

The amounts and small-scale spatial variation of micro-algae were estimated using measures of chl a from the top halves of the plates (due to the cover of macro-algae on the lower parts of concrete plates) from the CIR camera images. To test the hypothesis
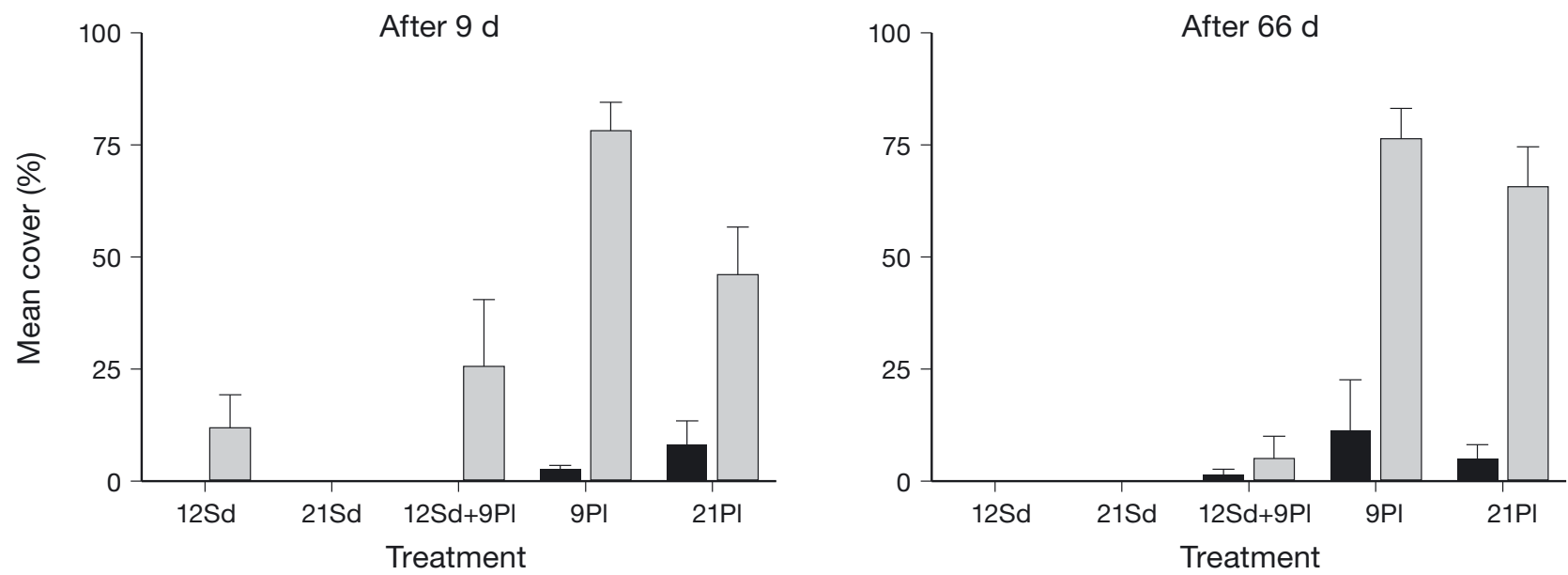

Fig. 4. Mean $\left( \pm \mathrm{SE}_{i} \mathrm{n}=4\right) \%$ cover of ephemeral green macro-algae on the lower parts of concrete and sandstone plates after 9 or $66 \mathrm{~d}$ for each experimental treatment (see 'Materials and methods' for treatment descriptions); data averaged across locations; black bars: sandstone plates; grey bars: concrete plates 
that the amount and/or spatial variance in biomass of micro-algae was affected by location, substratum or treatment, the biomass of chlorophyll $\left(\mu \mathrm{g} \mathrm{cm}^{-2}\right)$ in the upper $40 \%$ of each plate was derived from areas extracted from each image, in a nested design incorporating 4 spatial scales, with 2 levels of each scale. There were 2 independent sets of data incorporating a large scale (i.e. sampled $12 \mathrm{~cm}$ apart), a medium scale (4 cm apart) and a small scale (2 cm apart), with 2 replicate areas of $0.25 \mathrm{~cm}^{2}$ placed $1 \mathrm{~cm}$ apart. Care was taken to ensure that measures were only taken over areas with no erect macro-algae.

These data were analysed for locations (random factor), substrata (fixed factor) and treatment (fixed factor), with plates nested inside the interaction and the large, medium and small scales nested in plates. Data were analysed for 2 time periods, 17 and $95 \mathrm{~d}$ after the start of the experiment (Fig. 2). After $17 \mathrm{~d}$, there was significant small-scale variation in the amount of chlorophyll at scales of 2 and $4 \mathrm{~cm}$ and among replicate plates and a significant interaction between locations and substrata (Table 4). Supporting Hypothesis 7, there was significantly more chlorophyll on concrete than on sandstone at CC (Table 4). At CP, a similar pat-

Table 4. Analyses of biomasses of micro-algae $\left(\mu \mathrm{g} \mathrm{cm}^{-2}\right)$ estimated from the colour-infrared (CIR) camera on sandstone and concrete plates (substratum, fixed factor) at Careening Cove (CC) and Cremorne Point (CP) (locations, random factor) in 5 treatments $(9 \mathrm{Pl}, 21 \mathrm{Pl}, 9 \mathrm{Pl}+12 \mathrm{Sd}, 12 \mathrm{Sd}$ and $21 \mathrm{Sd}$, fixed factor; Treatments B, E, C, A, D, respectively, as described in 'Materials and methods'), for 3 spatial scales of variation within each plate (large, medium, or small; see 'Results - Amounts and types of algae' for details); Time 1: $17 \mathrm{~d}$ and Time 2: $95 \mathrm{~d}$ after Start 1. P: plate; G: large; M: medium; D: small. See Table 1 for other abbreviations. ${ }^{*} \mathrm{p}<0.05,{ }^{* *} \mathrm{p}<0.01,{ }^{* * *} \mathrm{p}<0.001$

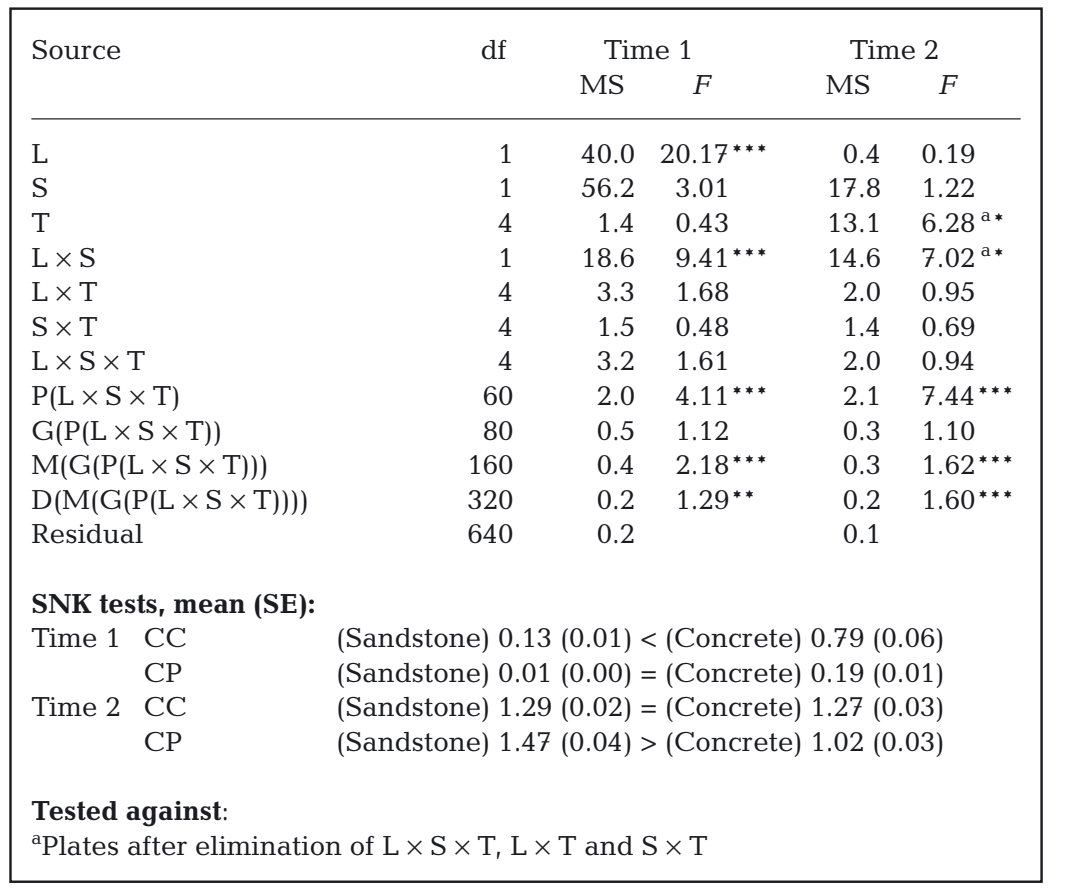

tern was found, but the difference was not significant (SNK test, $\mathrm{p}>0.05$ ). Treatments did not differ significantly, but there was less chlorophyll in the treatment with large than in the treatment with small densities of Siphonaria denticulata (mean \pm SE: $21 \mathrm{Sd}=0.20 \pm 0.02$; $12 \mathrm{Sd}=0.40 \pm 0.07 \mu \mathrm{g} \mathrm{cm}^{-2}$ ), which is, at least, consistent with Hypothesis 8. This difference was not found for Patelloida latistrigata $(21 \mathrm{Pl}=0.28 \pm 0.04 ; 9 \mathrm{Pl}=$ $0.29 \pm 0.03 \mu \mathrm{g} \mathrm{cm}^{-2}$ ).

After $95 \mathrm{~d}$, variation at scales of 2 and $4 \mathrm{~cm}$, among replicate plates and the interaction among locations and substrata was again significant (Table 4). Microalgae were more abundant overall, with smaller differences between locations and substrata, although at $\mathrm{CP}$, abundance was significantly greater on sandstone than on concrete plates (Table 4), so Hypothesis 7 (differences between substrata) is supported. At CC, a similar pattern was found, but the difference was not significant (SNK test, $\mathrm{p}>0.05$ ). Treatments differed significantly, with significantly less chlorophyll with densities of 21 Patelloida latistrigata $(0.97 \pm 0.02 \mu \mathrm{g}$ $\mathrm{cm}^{-2}$ ) than in the other treatments, which ranged from $1.16 \pm 0.03 \mu \mathrm{g} \mathrm{cm}^{-2}$ for the 12 Siphonaria denticulata with 9 P. latistrigata to $1.56 \pm 0.04 \mu \mathrm{g} \mathrm{cm}^{-2}$ for 12

$S$. denticulata alone. These outcomes partially support Hypothesis 8.

Because of the large amounts of smallscale variability in the biomass of chlorophyll and the different modes of feeding of the 2 species, the hypothesis that the scales of spatial variation in chlorophyll differs between substrata and treatments was tested by extracting the components of variation from the mean square (MS) values for $12,4,2 \mathrm{~cm}$ and the residual for each plate separately (Underwood 1997) and analysing each of these in ANOVAs with locations (random), substrata and treatments (fixed; $\mathrm{n}=4$ ).

At neither time were there any significant differences among any factors for variation at the scale of $12 \mathrm{~cm}$, but significant differences between substrata were found for $4 \mathrm{~cm}$ (Time 1), $2 \mathrm{~cm}$ (Time 1), significant interaction with locations (at Time 2) and the residual variance (both times). Consistent with the prediction (Hypothesis 7) that micro-algal assemblages would differ between substrata, there was more variability (i.e. spatial patchiness) in the biomass of micro-algae on concrete than on sandstone in all cases, except for the $4 \mathrm{~cm}$ scale at CC at Time 2, where the trend 
was similar, but not significant. There were no differences among treatments except for the residual variation at Time 2, where SNK tests failed to identify which treatments differed. It is not possible to interpret such results as supporting Hypotheses 8 or 9.

The data from the spectrometer were also analysed 17 and $95 \mathrm{~d}$ from the start of the experiment to identify whether there were differences in the relative abundances of the different pigments according to location, substratum, or treatment. Because of large differences in the biomass of chlorophyll between the locations and substrata, the estimates of carotenoids (determined from the peak at $\sim 546 \mathrm{~nm})$, phyco-erythrocyanin $(\sim 575 \mathrm{~nm})$, chlorophyll $C$ (chl $\left.C_{i} \sim 640 \mathrm{~nm}\right)$ and chlorophyll $b$ (chl $b_{;} \sim 650 \mathrm{~nm}$ ) were standardized according to the overall amount of chlorophyll, by dividing each value by the value of $\mathrm{chl}$ a $(\sim 680 \mathrm{~nm})$ for that spectrum. These data were averaged to give one measure per plate and analysed as a multivariate data set using PERMANOVA (Anderson 2001) for each location separately, with substratum orthogonal to treatment (each a fixed factor) on standardized Euclidean distances, with 999 permutations of the reduced model.

After $17 \mathrm{~d}$, there were no differences in the suite of pigments at $\mathrm{CC}$ (all $\mathrm{p}>0.05$ ), but at $\mathrm{CP}$ the relative amounts of the different pigments differed between sandstone and concrete (at $\mathrm{p}<0.01$ ), which, for this site, is consistent with Hypothesis 7. After $95 \mathrm{~d}$, the pigments differed among substrata at $\mathrm{CC}(\mathrm{p}<0.01)$ and CP ( $p<0.01$; Fig. 5A). There was relatively more phyco-erythrocyanin and chl $b$ on concrete and more chl $c$ on sandstone (illustrated for CP, Time 2 in Fig. 5B).

At $\mathrm{CP}$ after $95 \mathrm{~d}$, the data did not support Hypotheses 8 or 9 ; there was a difference among treatments $(\mathrm{p}<$ 0.05), but post-hoc pair-wise tests failed to find significant differences between any pairs of treatments. Similarly, there were no clear patterns in relative amounts of the different pigments according to the species present or their densities (Fig. 5C).

\section{Rates of grazing}

Because of the large cover of macro-algae on the lower $40 \%$ of the concrete plates, the discs used to measure grazing were separated into those placed on the higher $40 \%$ of each plate and those placed on the lower $40 \%$ of each plate, with 2 plates randomly assigned to each height (to maintain independence of data). Because the number of limpets deployed and survivorship varied among plates, the number of segments scratched was standardised to the mean number of limpets (each species separately) per plate, calculated from the numbers present when the discs were
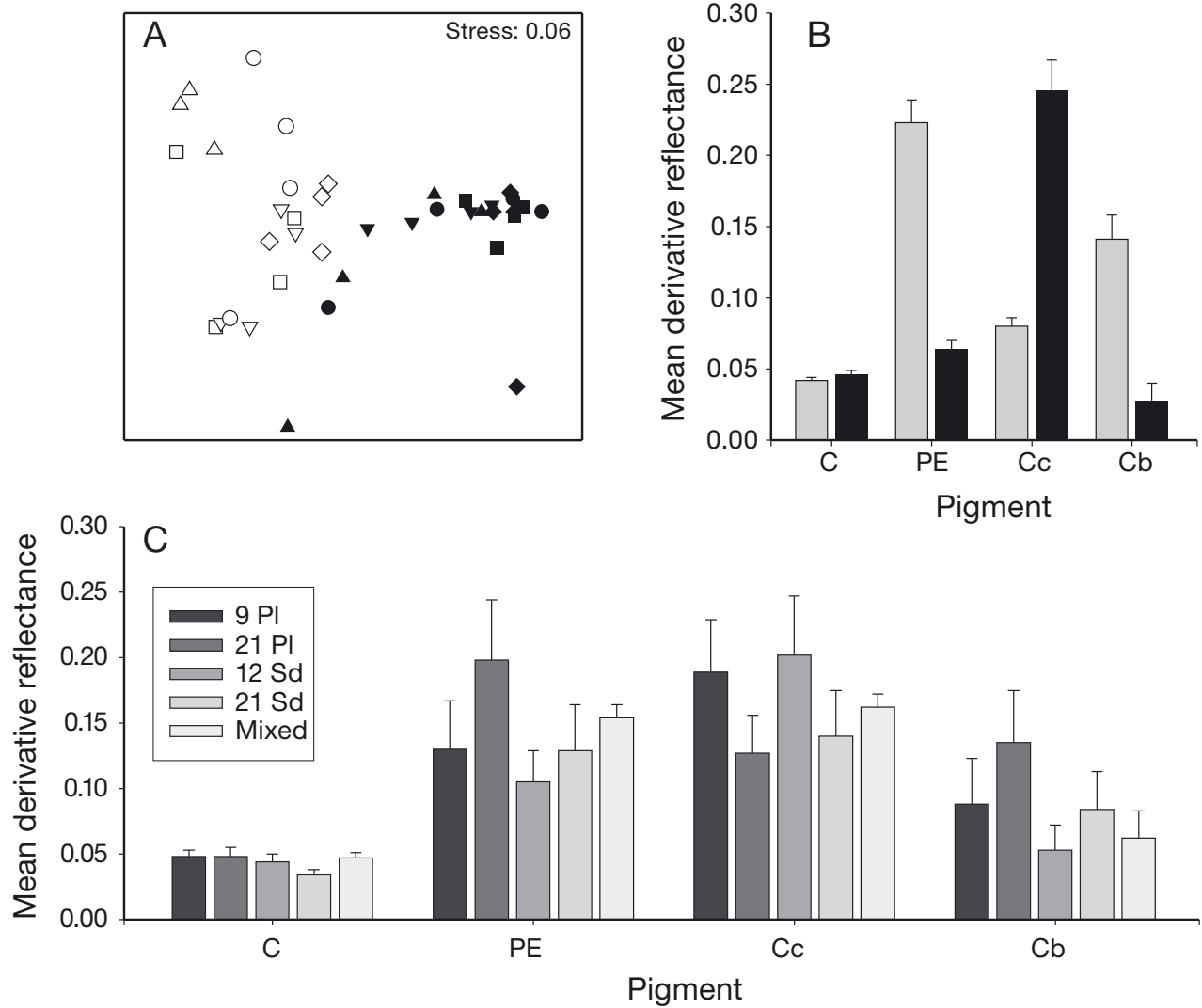

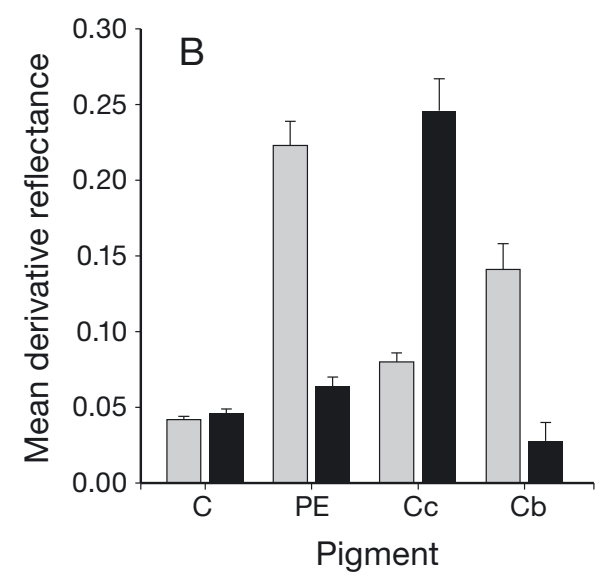

Fig. 5. (A) nMDS plot of derivative reflectance from 4 spectral pigment bands, corrected for biomass of chlorophyll a (chl a) for Cremorne Point, $95 \mathrm{~d}$ after the start of the experiment; $\mathbf{\square}, \square, 12$ Siphonaria denticulata; $\boldsymbol{\Delta}, \Delta$, 21 S. denticulata; $\boldsymbol{\nabla}, \nabla, 9$ Patelloida latistrigata; $\bullet, 0$, 21 P. latistrigata; $\diamond \diamond, 12$ $S$. denticulata and 9 P. latistrigata (see 'Materials and methods' for treatments); black symbols: sandstone plates; white symbols: concrete plates; (B) mean $( \pm \mathrm{SE}$; $\mathrm{n}=20$ ) derivative reflectance (unitless) for each pigment band $(\mathrm{C}=$ carotenoids; $\mathrm{PE}=$ phyco-erythrocyanin; $\mathrm{CC}=$ chlorophyll $c_{i} \mathrm{Cb}=$ chlorophyll $b$ ) for concrete (grey bars) and sandstone (black bars) averaged across treatments; $(C)$ mean $( \pm S E ; n=8)$ derivative reflectance for each pigment band for each treatment (details in key), averaged across substrata 
deployed and the numbers present when the discs were collected.

The wax discs were collected 35 (Time 1), 46 (Time 2) and $21 \mathrm{~d}$ (Time 3) after they were deployed (Fig. 2). The numbers of sectors grazed by each species were analysed using ANOVAs for each species separately, with location (random; 2 levels), substratum (fixed; 2 levels), treatment (fixed; 3 levels per species), height on the plate (fixed; 2 levels), 2 plates nested inside the combination of all factors; $\mathrm{n}=2$ discs per plate (Tables $5 \& 6$ ).

Differences among locations, substrata, treatments and heights on the shore in the amounts of grazing by $\mathrm{Si}$ phonaria denticulata were inconsistent among the 3 different times (Table 5). There was no consistent support for Hypothesis 10, because there were few significant differences in comparisons between sandstone and concrete plates (Table 5) and there were no general trends among treatments, nor between locations. For example, although there was less grazing per individual where there were $21 S$. denticulata than where there were $12 S$. denticulata in 14 of the 24 comparisons (i.e. 2 locations $\times 2$ substrata $\times 2$ heights $\times 3$ times), the opposite occurred in the other 10 comparisons. Similarly, in contrast to Hypothesis 11 (that grazing would be affected by substratum and the species of grazers present), adding Patelloida latistrigata to $S$. denticulata had no consistent effect on rates of grazing of $S$. denticulata. Of the 24 comparisons of grazing by $12 S$. denticulata plus 9 P. latistrigata versus 12 $S$. denticulata alone, 15 showed more grazing when the $S$. denticulata were alone, but 9 showed more grazing when the $S$. denticulata were with $P$. latistrigata. Despite there being so few significant differences in multiple comparisons, there was a tendency for less grazing on the upper than the lower parts of the plates, but this was not consistent among substrata, treatments, nor locations (Table 5).

There were similarly no general patterns among the 3 replicate deployments in rates of grazing by Patelloida latistrigata between locations, sub-
Table 5. Analyses of the numbers of sectors per wax disc grazed per individual Siphonaria denticulata at CC and CP (locations, random factor) on sandstone and concrete plates (substratum, fixed factor) in 3 treatments $(12 \mathrm{Pl}, 21 \mathrm{Sd}$ and $12 \mathrm{Sd}+9 \mathrm{Pl}$, fixed factor; treatments $\mathrm{A}, \mathrm{D}$ and $\mathrm{C}$, respectively, as described in 'Materials and Methods') at 2 vertical heights (high, low) on each plate, with 2 plates selected randomly per combination of factors; $n=2$ discs per plate; Time 1: $35 \mathrm{~d}$ after 1st deployment; Time 2: $46 \mathrm{~d}$ after 2nd deployment; and Time 3: $21 \mathrm{~d}$ after $3 r d$ deployment of discs. H: height. See Tables $1 \& 4$ for other abbreviations. ${ }^{\mathrm{ns}} \mathrm{p}>0.05,{ }^{*} \mathrm{p}<0.05,{ }^{* *} \mathrm{p}<0.01,{ }^{* * *} \mathrm{p}<0.001$

\begin{tabular}{|c|c|c|c|c|c|c|c|c|}
\hline \multirow{2}{*}{\multicolumn{2}{|c|}{ Source }} & \multirow[t]{2}{*}{ df } & \multicolumn{2}{|c|}{ Time 1} & \multicolumn{2}{|c|}{ Time 2} & \multicolumn{2}{|c|}{ Time 3} \\
\hline & & & MS & $F$ & MS & $F$ & MS & $F$ \\
\hline \multicolumn{2}{|l|}{ L } & 1 & 0.94 & $20.88^{\mathrm{C} * * *}$ & 3.39 & $56.91^{\mathrm{f} * * *}$ & 0.61 & $8.36^{\mathrm{h} * *}$ \\
\hline \multicolumn{2}{|l|}{ S } & 1 & 0.24 & 0.67 & 0.01 & 0.01 & 0.58 & $8.02^{\mathrm{h} * *}$ \\
\hline \multicolumn{2}{|l|}{$\mathrm{T}$} & 2 & 0.29 & $6.40^{* *}$ & 0.57 & 1.28 & 0.60 & 3.05 \\
\hline \multicolumn{2}{|l|}{$\mathrm{H}$} & 1 & 0.48 & 6.82 & 0.71 & $11.90^{\mathrm{f} * *}$ & 2.90 & 18.97 \\
\hline \multicolumn{2}{|l|}{$\mathrm{L} \times \mathrm{S}$} & 1 & 0.37 & $8.34^{\mathrm{c} * *}$ & 0.68 & $11.08^{\mathrm{e} * *}$ & 0.08 & $1.23^{\mathrm{g}}$ \\
\hline \multicolumn{2}{|l|}{$\mathrm{L} \times \mathrm{T}$} & 2 & 0.06 & $1.44^{\mathrm{c}}$ & 0.45 & $7.26^{\mathrm{e} * *}$ & 0.20 & $2.72^{\mathrm{g}}$ \\
\hline \multicolumn{2}{|c|}{$\mathrm{L} \times \mathrm{H}$} & 1 & 0.07 & $1.62^{\mathrm{C}}$ & 0.00 & $0.00^{\mathrm{e}}$ & 0.15 & $2.12^{\mathrm{g}}$ \\
\hline \multicolumn{2}{|c|}{$\mathrm{S} \times \mathrm{T}$} & 2 & 0.11 & $2.56^{\mathrm{c}}$ & 0.07 & $1.11^{\mathrm{e}}$ & 0.21 & $2.92^{9}$ \\
\hline \multicolumn{2}{|c|}{$\mathrm{S} \times \mathrm{H}$} & 1 & 0.07 & 0.09 & 0.04 & 0.15 & 0.01 & $0.14^{g}$ \\
\hline \multicolumn{2}{|c|}{$\mathrm{T} \times \mathrm{H}$} & 2 & 0.04 & 0.27 & 0.00 & 0.04 & 0.08 & $1.07^{\mathrm{g}}$ \\
\hline \multicolumn{2}{|c|}{$\mathrm{L} \times \mathrm{S} \times \mathrm{T}$} & 2 & 0.04 & $0.88^{\mathrm{b}}$ & 0.03 & $0.59^{\mathrm{d}}$ & 0.03 & $0.32^{\mathrm{d}}$ \\
\hline \multicolumn{2}{|c|}{$\mathrm{L} \times \mathrm{S} \times \mathrm{H}$} & 1 & 0.07 & $1.59^{\mathrm{b}}$ & 0.29 & $4.41^{\mathrm{d} *}$ & 0.00 & $0.04^{\mathrm{d}}$ \\
\hline \multicolumn{2}{|c|}{$\mathrm{L} \times \mathrm{T} \times \mathrm{H}$} & 2 & 0.14 & $3.27^{\mathrm{b}}$ & 0.10 & $1.59^{\mathrm{d}}$ & 0.02 & $0.26^{\mathrm{d}}$ \\
\hline \multicolumn{2}{|c|}{$\mathrm{S} \times \mathrm{T} \times \mathrm{H}$} & 2 & 0.06 & $0.28^{\mathrm{b}}$ & 0.04 & $0.60^{\mathrm{d}}$ & 0.06 & $0.68^{\mathrm{d}}$ \\
\hline \multicolumn{2}{|c|}{$\mathrm{L} \times \mathrm{S} \times \mathrm{T} \times \mathrm{H}$} & 2 & 0.05 & $1.13^{\mathrm{a}}$ & 0.08 & 1.25 & 0.07 & 0.87 \\
\hline \multicolumn{2}{|c|}{$\mathrm{P}(\mathrm{L} \times \mathrm{S} \times \mathrm{T} \times \mathrm{H})$} & 24 & 0.04 & 1.21 & 0.07 & $3.63^{* * *}$ & 0.08 & $3.07^{* * *}$ \\
\hline \multicolumn{2}{|c|}{ Residual } & 48 & 0.04 & & 0.02 & & 0.03 & \\
\hline \multicolumn{2}{|c|}{ Cochran's test $(C)$} & \multicolumn{3}{|c|}{$0.18^{\mathrm{ns}}$} & \multicolumn{2}{|c|}{$0.27^{*}$} & \multicolumn{2}{|c|}{$0.16^{\mathrm{ns}}$} \\
\hline SNK & ests, mean (S & & & & & & & \\
\hline Time & $1 \mathrm{~L} \times \mathrm{H} \times \mathrm{S}$ & & & & & & & \\
\hline $\mathrm{CC}$ & High & $\begin{array}{l}(21 \mathrm{Sd} \\
0.44(\end{array}$ & $\begin{array}{l}0.29 \\
0.09)\end{array}$ & $(0.06)=($ & $(12 \mathrm{Sd})$ & $0.46(0.10)$ & $<(12$ & $\mathrm{Sd}+9 \mathrm{Pl})$ \\
\hline & Low & $\begin{array}{l}(21 \mathrm{Sd} \\
0.75\end{array}$ & $\begin{array}{l}0.39 \\
0.01)\end{array}$ & $(0.04)<$ & 12Sd) & $0.64(0.07)$ & $=(12 \mathrm{~s}$ & $\mathrm{Sd}+9 \mathrm{Pl})$ \\
\hline $\mathrm{CP}$ & High & $\begin{array}{l}(21 \mathrm{Sd} \\
0.40(\end{array}$ & $\begin{array}{l}0.19 \\
0.08)\end{array}$ & $(0.07)=$ & 12Sd) & $0.16(0.06)$ & $<(12 S$ & $\mathrm{Sd}+9 \mathrm{Pl})$ \\
\hline & Low & $\begin{array}{l}\text { (21Sd } \\
0.30\end{array}$ & $\begin{array}{l}0.29 \\
0.11)\end{array}$ & $(0.04)<$ & $12 \mathrm{Sd})$ & $0.43(0.11)$ & $=(12 \mathrm{~S}$ & $\mathrm{Sd}+9 \mathrm{Pl})$ \\
\hline All C & omparisons b & etween & heigh & hts non-sigr & nifican & $t$, except & & \\
\hline $\mathrm{CC}$ & $12 \mathrm{Sd}+9 \mathrm{Pl}$ & (High & ) 0.40 & $(0.08)<(\mathrm{Lc}$ & ow) 0.7 & 75 (0.01) & & \\
\hline $\mathrm{CP}$ & $12 \mathrm{Sd}$ & (High & 0.15 & $(0.06)<(\mathrm{Lc}$ & ow) 0.4 & $43(0.11)$ & & \\
\hline Time & $2 \mathrm{~L} \times \mathrm{H} \times \mathrm{S}$ & & & & & & & \\
\hline $\mathrm{CC}$ & High & (Sand & Istone) & ) $0.68(0.05)$ & )$>(\mathrm{Co}$ & oncrete) 0.46 & $6(0.08)$ & \\
\hline & Low & (Sand & Istone) & $0.78(0.09)$ & )$=(\mathrm{Co}$ & oncrete) 0.7( & $0(0.06$ & \\
\hline $\mathrm{CP}$ & High & (Sand & Istone) & $0.02(0.02)$ & )$<(\mathrm{Co}$ & oncrete) 0.37 & $7(0.06)$ & \\
\hline & Low & (Sand & Istone) & $0.35(0.08)$ & )$=(\mathrm{Co}$ & oncrete) 0.38 & $8(0.09)$ & \\
\hline Time & $2 \mathrm{~L} \times \mathrm{T}$ & & & & & & & \\
\hline $\mathrm{CC}$ & & $\begin{array}{l}(21 \mathrm{Sd} \\
0.87\end{array}$ & $\begin{array}{l}0.38 \\
0.05)\end{array}$ & $(0.05)<$ & $12 \mathrm{Sd})$ & $0.72(0.02)$ & $=(12 \mathrm{~s}$ & $\mathrm{Sd}+9 \mathrm{Pl})$ \\
\hline $\mathrm{CP}$ & & $\begin{array}{l}(21 \mathrm{Sd} \\
0.30\end{array}$ & $\begin{array}{l}0.26 \\
0.08)\end{array}$ & $(0.05)=($ & $12 \mathrm{Sd})$ & $0.28(0.08)$ & $=(12 \mathrm{~s}$ & $\mathrm{Sd}+9 \mathrm{Pl})$ \\
\hline
\end{tabular}

Time $3 \mathrm{~S}$

(Sandstone) $0.36(0.04)<($ Concrete) $0.52(0.05)$

\section{Tested against:}

apooled Residual and $\mathrm{P}(\mathrm{L} \times \mathrm{S} \times \mathrm{T} \times \mathrm{H})$

${ }^{b}$ Pooled Residual, $\mathrm{P}(\mathrm{L} \times \mathrm{S} \times \mathrm{T} \times \mathrm{H})$ and $\mathrm{L} \times \mathrm{S} \times \mathrm{T} \times \mathrm{H}$

cPooled Residual, $\mathrm{P}(\mathrm{L} \times \mathrm{S} \times \mathrm{T} \times \mathrm{H}), \mathrm{L} \times \mathrm{S} \times \mathrm{T} \times \mathrm{H}$ and $\mathrm{L} \times \mathrm{S} \times \mathrm{T}$

${ }^{\mathrm{d} P o o l e d} \mathrm{P}(\mathrm{L} \times \mathrm{S} \times \mathrm{T} \times \mathrm{H})$ and $\mathrm{L} \times \mathrm{S} \times \mathrm{T} \times \mathrm{H}$

epooled $\mathrm{P}(\mathrm{L} \times \mathrm{S} \times \mathrm{T} \times \mathrm{H}), \mathrm{L} \times \mathrm{S} \times \mathrm{T} \times \mathrm{H}$ and $\mathrm{L} \times \mathrm{S} \times \mathrm{T}$

${ }^{\mathrm{f}}$ Pooled $\mathrm{P}(\mathrm{L} \times \mathrm{S} \times \mathrm{T} \times \mathrm{H}), \mathrm{L} \times \mathrm{S} \times \mathrm{T} \times \mathrm{H}, \mathrm{L} \times \mathrm{S} \times \mathrm{T}$ and $\mathrm{L} \times \mathrm{H}$

gPooled $\mathrm{P}(\mathrm{L} \times \mathrm{S} \times \mathrm{T} \times \mathrm{H}), \mathrm{L} \times \mathrm{S} \times \mathrm{T} \times \mathrm{H}, \mathrm{L} \times \mathrm{T} \times \mathrm{H}, \mathrm{L} \times \mathrm{S} \times \mathrm{H}$ and $\mathrm{L} \times \mathrm{S} \times \mathrm{T}$

hPooled $\mathrm{P}(\mathrm{L} \times \mathrm{S} \times \mathrm{T} \times \mathrm{H}), \mathrm{L} \times \mathrm{S} \times \mathrm{T} \times \mathrm{H}, \mathrm{L} \times \mathrm{T} \times \mathrm{H}, \mathrm{L} \times \mathrm{S} \times \mathrm{H}, \mathrm{L} \times \mathrm{S} \times \mathrm{T}$ and $\mathrm{L} \times \mathrm{S}$ 
Table 6. Analyses of the numbers of sectors per wax disc grazed per individual Patelloida latistrigata at CC and CP (locations, random factor) on sandstone and concrete plates (substratum, fixed factor) in 3 treatments $(9 \mathrm{Pl}, 21 \mathrm{Pl}$, and $9 \mathrm{Pl}+$ 12Sd, fixed factor; Treatments B, E and C, respectively, as described in 'Materials and methods') at 2 vertical heights (high, low) on each plate, with 2 plates selected randomly per combination of factors; $\mathrm{n}=2$ discs per plate; Time 1: $35 \mathrm{~d}$ after 1st deployment; Time 2: $46 \mathrm{~d}$ after 2nd deployment; and Time 3: $21 \mathrm{~d}$ after 3rd deployment of wax discs. See Tables $1,4 \& 5$ for other abbreviations. ${ }^{\mathrm{ns}} \mathrm{p}>0.05,{ }^{*} \mathrm{p}<0.05,{ }^{* *} \mathrm{p}<0.01,{ }^{* * *} \mathrm{p}<0.001$

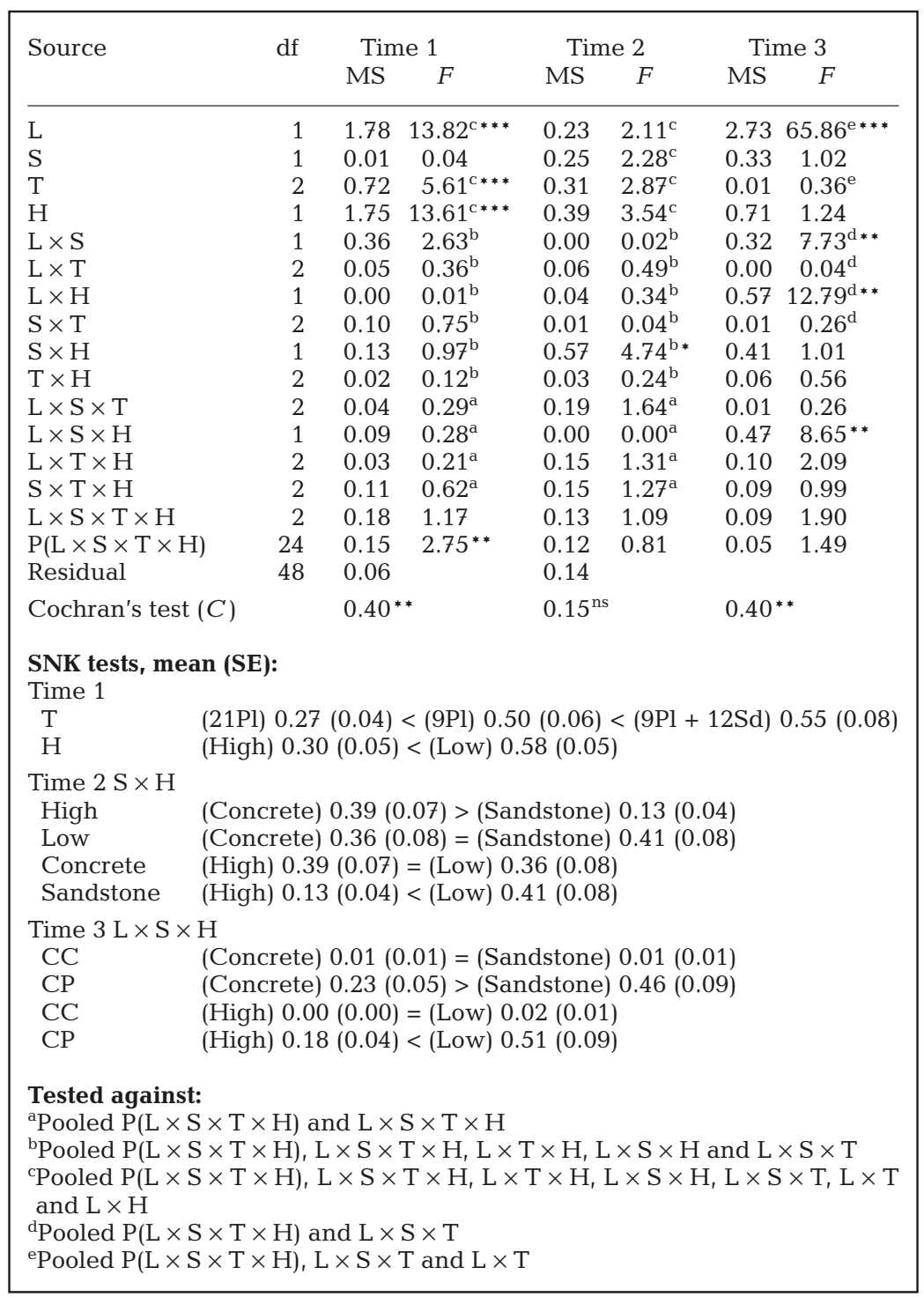

strata, treatments, or heights (Table 6). For example, contrary to Hypothesis 10, there was no consistent effect of substratum, which varied inconsistently according to the location (Time 3) or the height at which the limpets were grazing (Time 2). Treatments only differed significantly in the first deployment, when the mean number of sectors grazed per individual was smaller for the treatment with $21 P$. latistrigata than for those with $9 P$. latistrigata, irrespective of the presence or absence of Siphonaria denticulata. These outcomes provide partial support for Hypothesis 11, but reject Hypothesis 12. This could have been due to an experimental artefact, because all sectors were grazed on many plates. Therefore, standardizing by dividing by the number of snails artificially lowered the rate of grazing in the large density treatment. This did not occur in the other deployments where the discs were recovered before they were so extensively grazed and the pattern found at Time 1 did not occur. As for $S$. denticulata, the limpets tended to graze more lower than higher on the plates on both substrata, but differences were not always significant (Table 6). There was no indication that S. denticulata or increased densities of $P$. latistrigata changed whereabouts on the plates the limpets fed.

\section{DISCUSSION}

In NSW, there are many species of interacting intertidal grazers and an extremely diverse assemblage (Dakin 1953, Stephenson \& Stephenson 1972). Despite many papers in recent years documenting patterns of assemblages on seawalls, few have compared ecological interactions among animals between artificial and natural shores. Bulleri et al. (2004) showed grazing by Cellana tramoserica on walls differed from that on natural shores in NSW, which could have major impacts on assemblages because of its strong interactions with other species (Underwood et al. 1983, Underwood 1984, 1985). Intertidal shores in NSW are generally extensive wave-cut platforms, so interactions among grazers might be expected to be stronger on seawalls where the intertidal area is reduced and species are crowded into a limited area.

Siphonaria denticulata have greater densities on many sandstone seawalls in Sydney Harbour than on natural shores. Patelloida latistrigata are more common on concrete than on sandstone walls. S. denticulata graze on fronds of macro-algae and do not remove algal propagules as do patellid or acmaeid limpets, such as P. latistrigata (Underwood \& Jernakoff 1981). 
Thus, micro-algal food may persist in the presence of large densities of $S$. denticulata. Patellid limpets, in contrast, remove nearly all algal spores and many species outcompete siphonarian limpets, although they seldom cause local extinctions because of strong intraspecific competition (Creese \& Underwood 1982, Ortega 1985, Lasiak \& White 1993). Thus, changes in competitive interactions, types or amounts of food, or differences in recruitment might explain the pattern of greater densities of $S$. denticulata on sandstone walls and greater densities of $P$. latistrigata on concrete walls.

Unfortunately, too few Patelloida latistrigata recruited during the experiment for detailed analysis, although all but one recruited onto concrete. Thus, recruitment may explain larger densities of $P$. latistrigata on concrete walls. What caused this is not known, although some gastropods settle in response to biofilms (Kay 2002), which may differ between substrata. Concrete is also a strong inducer to settlement of oysters, irrespective of biofilm (Anderson 1996). There were too few data to be able to test whether Siphonaria denticulata affected recruitment of $P$. latistrigata.

Recruitment of Siphonaria denticulata was more complex. They recruited more to concrete than to sandstone, although adults are more abundant on sandstone. Recruitment increased in the presence of conspecifics (Kay 2002, Zhao \& Qian 2002), but decreased in the presence of Patelloida latistrigata. Adult limpets can reduce densities of juveniles by bull-dozing (Underwood et al. 1983), or, as described for Patella longicosta, by ejecting juveniles from territories (Branch 1975). For interactions between recruits and adults to explain the observed patterns of abundance of $S$. denticulata, P. latistrigata must have a stronger negative effect on small $S$. denticulata than do adult $S$. denticulata, possibly because they feed by scraping the substratum. S. denticulata may move over recruits without much damage. Unravelling this requires focused experiments about settlement and mortality of settlers on both surfaces in the presence/absence of each species.

Adults of each species survived better on concrete, although each was affected by adult Patelloida latistrigata. Increased densities of $P$. latistrigata reduced conspecific survival, as on natural shores (Creese 1982). They also decreased survival of Siphonaria denticulata, as shown for other patellid and siphonarian limpets (e.g. Underwood \& Jernakoff 1981, Creese \& Underwood 1982, Lasiak \& White 1993). This may have been due to removal of food or interference when feeding. Thus, if densities of $P$. latistrigata increase on concrete walls due to recruitment, their presence might further reduce any $S$. denticulata that survive settlement on these surfaces. The smaller rates of recruitment of $P$. latistrigata to sandstone might mean that they never reach large enough densities to affect recruiting $S$. denticulata on these surfaces.

Siphonaria denticulata did not affect mortality of Patelloida latistrigata, as shown for other species (Creese \& Underwood 1982, Ortega 1985), but in contrast to the interaction between Siphonaria concinna and Cellana capensis (Lasiak \& White 1993). Thus, the presence of adult $S$. denticulata is unlikely to explain patterns of abundance of either species between sandstone and concrete seawalls. In general, the competitive interactions on seawalls reflect what occurs on natural shores, even though intra- and interspecific competition were expected to be more severe on walls due to the limited number of refuges and the small amount of intertidal habitat.

Interactions between limpets and their resources are complex, including interference competition (Stimson 1970), defence of 'gardens' (Stimson 1970, Wright 1982) and removal of resources (Dayton 1971, Branch 1975, Underwood 1978, 1984). Because Patelloida latistrigata and Siphonaria denticulata exploit different algal resources, patterns of development of micro- and macro-algae were examined to determine whether these could explain the patterns of the adult limpets. Ephemeral macro-algae, which are eaten by $S$. denticulata, developed as a thick band on the lower halves of the concrete plates. These algae are not particularly common on well-established sandstone or concrete seawalls (Bulleri et al. 2005, Moreira 2006), where oysters and tubeworms are major components of the assemblages (Moreira 2006). Ephemeral algae commonly colonize new, damp surfaces (Bacchiocchi \& Airoldi 2003) or areas with few grazers (Pinn et al. 2005). They rapidly colonize newly built seawalls in Sydney Harbour, but usually low on the shore (M. G. Chapman pers. obs.). The concrete plates may have retained more water during low tide than did the sandstone plates, remaining damp like low-shore areas. There was a smaller cover of macro-algae where there were larger densities of $S$. denticulata, indicating that these limpets were exploiting this resource, as would be predicted from their known ecology. Increased survival of $S$. denticulata on concrete may therefore be, in part, due to concrete having more macro-algae, even though there was no evidence of intraspecific competition on either surface.

Amounts of macro-algae were not influenced by densities of Patelloida latistrigata, despite the fact that this species can eat macro-algae (Jernakoff 1985). The reduced amounts of space for development of the micro-algal assemblage due to space occupied by macro-algae did not alter either intra- or interspecific effects of this limpet. Micro-algae were also more abundant on concrete plates, although differences between surfaces decreased with longer periods of de- 
ployment. Where large amounts of macro-algae cover the substratum on natural shores, they inhibit recruitment of $P$. latistrigata and survival of this and other limpets (Underwood et al. 1983). This was, however, not shown here, where both species survived better and $P$. latistrigata recruited more where there were greater covers of macro-algae. Thus, the development of ephemeral macro-algal assemblages cannot explain the patterns of Siphonaria denticulata reported by Moreira (2006).

Amounts of micro-algae were reduced by large densities of Patelloida latistrigata, as predicted from patterns shown on natural shores. Siphonaria denticulata, again as predicted from their known ecology, had no major effects on micro-algae. The composition of the micro-algal assemblage and its spatial variation differed between the 2 substrata, but this was not affected by the types or numbers of limpets present.

It was surprising that there was no clear pattern in grazing activities of the 2 species. Given that Siphonaria denticulata eat macro-algae, it would have been expected to find more grazing by $S$. denticulata on lower parts of the plates. In contrast, Patelloida latistrigata would have been expected to graze more on the upper parts of plates, where macro-algae were sparse and there was more access to areas covered by microalgae. Where P. latistrigata were numerous, because they consume micro-algae, including early stages of development of macro-algae, $S$. denticulata should have been even more likely to feed on lower parts of plates where their food was more abundant. In fact, there were no influences of either species on the other, in terms of where they fed. If anything, each species tended to forage more on lower parts of plates, but that cannot be explained by known aspects of their ecology on natural substrata.

There was more phyco-erythrocyanin and chl $b$ on concrete and more chl $c$ on sandstone plates, which suggests relatively more green micro-algae and cyanobacteria on concrete and relatively more diatoms on sandstone. Increased amounts of green micro-algae on concrete may, at least in part, be due to increased numbers of sporelings of the ephemeral macro-algae that developed on this substratum. Although cyanobacteria may have limited value as food for grazers, Nagarkar et al. (2004) found that epilithic cyanobacteria can be superior as food over other micro-algae, in terms of their protein, calorific content and, sometimes, carbohydrates. Thus, increased amounts of microalgae, plus their composition, may have explained greater survival of each species on concrete.

The assemblage of micro-algae was, however, not affected by the mix of limpets, which is surprising considering their different modes of feeding. There was more small-scale patchiness of micro-algae on concrete than on sandstone, possibly due to the substratum, or to differences in the ways the species grazed on the different surfaces. Little is known about the complex causes of small-scale patchiness of abundances of micro-algae on intertidal rocky shores, although grazing by different species can cause differences in amounts (Underwood \& Murphy 2008) and types (Murphy \& Underwood 2006) of micro-flora present. Variations in abundances and types of micro-algae due to grazing are at spatial scales of $\mathrm{mm}$ to $\mathrm{cm}$ and have not been detectable until the development of methods over recent years to measure micro-algae in situ at the relevant small scales. Differences in such an important food resource may have important implications for the suite of species that can persist in the long-term on artificial structures, but have, as yet, received little attention. Because the procedures used here measure light reflected vertically from the surface, it is not possible to measure amounts of micro-algae on the vertical surfaces of seawalls, except on experimental surfaces that could be moved to a horizontal position for sampling. So, no comparisons were made between seawalls and natural shores.

Thus, the material used to build artificial structures may influence rates of recruitment, the amounts and types of food resources, or the quality of habitat due to the lack of many macro-habitats (Moreira et al. 2006, Chapman \& Blockley 2009). Here, 2 species of limpets that have complex competitive interactions with numerous other species on natural shores showed similar complex interactions on plates attached to vertical seawalls, which varied according to the material of the plate. Despite our predictions, competition was not very great on seawalls, possibly because of adequate food. The results here cannot fully explain the patterns of distribution reported by Moreira (2006), perhaps because these interactions are more complex than originally thought, or other differences between substrata that were not investigated here, or because the concrete in the plates used here differed from that used to build walls, or because more time is needed to establish the relationships that led to the originally observed patterns.

Whatever is demonstrated by more complete analyses when they become available, several important points are demonstrated by the experiments described here. Processes were more complex and predicted interactions less clear than had been anticipated. This is important for developing useful frameworks for identifying and managing the core ecological processes that must be maintained to ensure maintenance of local patterns of biodiversity. Because grazing is such an important controlling process for many intertidal species (reviewed by Branch 1981, Hawkins \& Hartnoll 1983, Underwood 1985, 1992), it is one of the key processes to understand. The extent to which 
knowledge about such a well-studied topic succeeded or failed to provide appropriate predictions for artificial habitats is instructive. It demonstrates that care will particularly be needed where the processes in natural habitats are less well-known or less amenable to experimental development of theory. Future increased needs of conservation of biodiversity in man-made habitats require more tests of the applicability of extant ecological knowledge and theories to increasingly stressed and altered shorelines.

Acknowledgements. This research was supported by an ARC Linkage Grant and a Sydney Aquarium Conservation Foundation Grant to M.G.C. and by the Centre for Research on Ecological Impacts of Coastal Cities, which provided a postdoctoral fellowship for L.I. Many research support staff assisted with fieldwork, data-entry and checking; particular thanks go to M. Day and C. Myers. We thank most reviewers for positive comments and help.

\section{LITERATURE CITED}

Anderson MJ (1996) A chemical cue induces settlement of Sydney rock oysters, Saccostrea commercialis in the laboratory and in the field. Biol Bull 190:350-358

Anderson MJ (2001) A new method for non-parametric multivariate analysis of variance. Austral Ecol 26:32-46

> Attrill MJ, Bilton DT, Rowden AA, Rundle SD, Thomas RM (1999) The impact of encroachment and bankside development on the habitat complexity and supralittoral invertebrate communities of the Thames Estuary foreshore. Aquat Conserv Mar Freshwat Ecosyst 9:237-247

$>$ Bacchiocchi F, Airoldi L (2003) Distribution and dynamics of epibiota on hard structures for coastal protection. Estuar Coast Shelf Sci 56:1157-1166

Bidigare RR, Morrow JH, Kiefer DA (1989) Derivative analysis of spectral absorptions by photosynthetic pigments in the western Sargasso Sea. J Mar Res 47:323-341

Branch GM (1975) Mechanisms reducing intraspecific competition in Patella species: migration, differentiation and territorial behaviour. J Anim Ecol 44:575-600

Branch GM (1981) The biology of limpets: physical factors, energy flow and ecological interactions. Ann Rev Oceanogr Mar Biol 19:235-280

Breuste J, Feldmann H, Uhlmann O (1998) Urban ecology. Springer Verlag, Berlin

Bulleri F, Airoldi L (2005) Artificial marine structures facilitate the spread of a non-indigenous green alga, Codium fragile ssp. tomentosoides, in the north Adriatic sea. J Appl Ecol 42:1063-1072

Bulleri F, Chapman MG, Underwood AJ (2004) Patterns of movement of the limpet Cellana tramoserica on rocky shores and retaining seawalls. Mar Ecol Prog Ser 281:121-129

Bulleri F, Chapman MG, Underwood AJ (2005) Intertidal assemblages on seawalls and rocky shores in Sydney Harbour (Australia). Austral Ecol 30:655-667

Bulleri F, Abbiati M, Airoldi L (2006) The colonisation of human-made structures by the invasive alga Codium fragile ssp tomentosoides in the north Adriatic Sea (NE Mediterranean). Hydrobiol 555:263-269

Chapman MG (2003) Paucity of mobile species on constructed seawalls: effects of urbanization on biodiversity. Mar Ecol Prog Ser 264:21-29
Chapman MG (2006) Intertidal seawalls as habitats for molluscs. J Moll Stud 72:247-257

Chapman MG, Blockley DG (2009) Engineering novel habitats on urban infrastructure to increase intertidal biodiversity. Oecologia 161:625-635

Chapman MG, Bulleri F (2003) Intertidal seawalls-new features of landscape in intertidal environments. Landsc Urban Plan 62:159-172

Creese RG (1982) Distribution and abundance of the acmaeid limpet, Patelloida latistrigata, and its interaction with barnacles. Oecologia 52:85-96

Creese RG, Underwood AJ (1982) Analysis of inter- and intraspecific competition among intertidal limpets with different method of feeding. Oecologia 53:337-346

Dakin WJ (1953) Australian sea shores. Angus \& Robertson, Sydney

Davis JLD, Levin LA, Walther SM (2002) Artificial armored shorelines: sites for open-coast species in a southern California bay. Mar Biol 140:1249-1262

$>$ Dayton PK (1971) Competition, disturbance, and community organization: the provision and subsequent utilization of space in a rocky intertidal community. Ecol Monogr 41: 351-389

Glasby TM, Connell SD (1999) Urban structures as marine habitats. Ambio 28:595-598

Goodsell PJ, Chapman MG, Underwood AJ (2007) Differences between biota in anthropogenically fragmented habitats and in naturally patchy habitats. Mar Ecol Prog Ser 351:15-23

Hawkins SJ, Hartnoll RG (1983) Grazing of intertidal algae by invertebrates. Ann Rev Oceanog Mar Biol 21:195-282

Jackson AC, Chapman MG, Underwood AJ (2008) Ecological interactions in the provision of habitat by urban development: whelks and engineering by oysters on artificial seawalls. Austral Ecol 33:307-316

> Jernakoff P (1985) An experimental evaluation of the influence of barnacles, crevices and the seasonal patterns of grazing on the algal diversity and cover in an intertidal barnacle zone. J Exp Mar Biol Ecol 88:287-302

Kay MC (2002) Recruitment in the intertidal limpet Lottia digitalis (Patellogastropoda: Lottiidae) may be driven by settlement cues associated with adult habitat. Mar Biol 141:467-477

Lasiak TA, White DRA (1993) Microalgal food reserves and competitive interactions among the intertidal limpets Cellana capensis (Gmelin, 1791) and Siphonaria concinna Sowerby, 1824. S Afr J Mar Sci 13:97-108

Laurie M (1979) Nature and city planning in the nineteenth century. In: Laurie IC (ed) Nature in cities. John Wiley \& Sons, Chichester, p 37-63

MacLulich JH (1986) Colonization of bare rock surfaces by microflora in a rocky intertidal habitat. Mar Ecol Prog Ser 32:91-96

Marzinelli EM, Zagal CJ, Chapman MG, Underwood AJ (2009) Do modified habitats have direct or indirect effects on epifauna? Ecology 90:2948-2955

> May RM (1994) Conceptual aspects of the quantification of the extent of biological diversity. Philos Trans R Soc London B 345:13-20

McIntyre NE (2000) Ecology of urban arthropods: a review and call to action. Ann Entomol Soc Am 93:825-835

Moreira J (2006) Patterns of occurrence of grazing molluscs on sandstone and concrete seawalls in Sydney Harbour (Australia). Molluscan Res 26:51-60

Moreira J, Chapman MG, Underwood AJ (2006) Seawalls do not sustain viable populations of limpets. Mar Ecol Prog Ser 322:179-188 
Moschella PS, Abbiati M, Åberg P, Airoldi L and others (2005) Low-crested coastal defence structures as artificial habitats for marine life: using ecological criteria in design. Coast Eng 52:1053-1071

Murphy RJ, Underwood AJ (2006) Novel use of digital colourinfrared imagery to test hypotheses about grazing by intertidal herbivorous gastropods. J Exp Mar Biol Ecol 330:437-447

Murphy RJ, Tolhurst TJ, Chapman MG, Underwood AJ (2004) Estimation of surface chlorophyll on an exposed mudflat using digital colour-infrared (CIR) photography. Estuar Coast Shelf Sci 59:625-638

Murphy RJ, Tolhurst TJ, Chapman MG, Underwood AJ (2005a) Estimation of surface chlorophyll $a$ on an exposed mudflat using field spectrometry: accuracy of ratios and derivativebased approaches. Int J Remote Sens 26:1835-1859

Murphy RJ, Underwood AJ, Pinkerton MH, Range P (2005b) Field spectrometry: new methods to investigate epilithic micro-algae on rocky shores. J Exp Mar Biol Ecol 325: 111-124

Murphy RJ, Underwood AJ, Pinkerton MH (2006) Quantitative imaging to measure photosynthetic biomass on an intertidal rock-platform. Mar Ecol Prog Ser 312:45-55

Nagarkar S, Williams GA, Subramanian G, Saha SK (2004) Cyanobacterial-dominated biofilms: a high quality food source for intertidal grazers. Hydrobiol 512:89-95

Ortega S (1985) Competitive interactions among tropical intertidal limpets. J Exp Mar Biol Ecol 90:11-25

Pinn EH, Mitchell K, Corkill J (2005) The assemblages of groynes in relation to substratum age, aspect and microhabitat. Estuar Coast Shelf Sci 62:271-282

Savitzky A, Golay MJE (1964) Smoothing and differentiation of data by simplified least squares procedures. Anal Chem 36:1627-1639

Smith CR, Austen MC, Boucher G, Heip C and others (2000) Global change and biodiversity linkages across the sediment-water interface. Bio Sci 50:1108-1120

Steinier J, Termonia Y, Deltour J (1972) Comments on smoothing and differentiation of data by simplified least square procedure. Anal Chem 44:1906-1909

Stephenson TA, Stephenson A (1972) Life between tide marks on rocky shores. W. H. Freeman, San Francisco, CA

Stimson J (1970) Territorial behaviour of the owl limpet, Lottia gigantea. Ecology 51:113-118

Editorial responsibility: Hans Heinrich Janssen, Oldendorf/Luhe, Germany
Suchanek TH (1994) Temperate coastal marine communities: biodiversity and threats. Am Zool 34:110-114

Thompson RC, Johnson LE, Hawkins SJ (1997) A method for spatial and temporal assessment of gastropod grazing intensity in the field: the use of radula scrapes on wax surfaces. J Exp Mar Biol Ecol 218:63-76

Underwood AJ (1978) An experimental evaluation of competition between three species of intertidal prosobranch gastropods. Oecologia 33:185-202

Underwood AJ (1984) Vertical and seasonal patterns in competition for microalgae between intertidal gastropods. Oecologia 64:211-222

Underwood AJ (1985) Physical factors and biological interactions: the necessity and nature of ecological experiments. In: Moore PG, Seed R (eds) The ecology of rocky coasts. Hodder \& Stoughton, London, p 372-390

Underwood AJ (1986) The analysis of competition by field experiments. In: Kikkawa J, Anderson DJ (eds) Community ecology pattern and process. Blackwell Scientific Publications, Melbourne, p 240-268

Underwood AJ (1992) Competition in marine plant-animal interactions. In: John DM, Hawkins SJ, Price JH (eds) Plant-animal interactions in the marine benthos. The Systematics Association Special Vol 46. Clarendon Press, Oxford, p 443-475

Underwood AJ (1997) Experiments in ecology: their logical design and interpretation using analysis of variance. Cambridge University Press, Cambridge

> Underwood AJ, Jernakoff P (1981) Effects of interactions between algae and grazing gastropods on the structure of a lowshore algal community. Oecologia 48:221-233

- Underwood AJ, Murphy RJ (2008) Unexpected patterns of facilitatory grazing revealed by quantitative imaging. Mar Ecol Prog Ser 358:85-94

Underwood AJ, Denley EJ, Moran MJ (1983) Experimental analyses of the structure and dynamics of the midshore intertidal communities in New South Wales. Oecologia 56: $202-219$

Wright WG (1982) Ritualized behaviour in a territorial limpet. J Exp Mar Biol Ecol 60:245-251

> Zhao B, Qian PY (2002) Larval settlement and metamorphosis in the slipper limpet Crepidula onyx (Sowerby) in response to conspecific cues and the cues from biofilm. J Exp Mar Biol Ecol 269:39-51

Submitted: July 28, 2009; Accepted: February 3, 2010 Proofs received from author(s): May 6, 2010 